\title{
Economic threshold and economic injury levels for the two spotted spider mite Tetranychus cucurbitacearum (Sayed) on soybean
}

\author{
Fatma Sh. Kalmosh \\ Plant Protection Research Institute, ARC, Dokki, Giza, Egypt. \\ Corresponding author: bkalmosh@yahoo.com
}

\begin{abstract}
Economic injury and economic threshold levels were estimated for the two spotted spider mite, Tetranychus cucurbitacearum (Sayed) (Acari, Tetranychidae) on soybean plants. An attempt was made to determine, mathematically, the point at which a significant reduction occurs in the yield of soybean at different levels of infestation by the two spotted spider mite, T. cucurbitacearum. For this purpose, counts were taken during each of the main three annual peaks of this mite infestation over two seasons of (2015and 2016). The obtained results indicated that the mean values of economic injury level were 28.97 and 22.01 individuals / leaflet, while mean values of economic threshold levels were 32.05 and 21.23 individuals / leaflet during 2015 and 2016 seasons, respectively, while the general mean of economic threshold and economic injury levels were 21.23 individuals per leaflet and 18.21 individuals per leaflet, respectively.
\end{abstract}

Key words: Acari, spider mite, Tetranychus cucurbitacearum, damage, economic threshold, injury level.

\section{Introduction}

Among phytophagous mites, the two-spotted spider mite Tetranychus cucurbitacearum, is the most important agricultural pests, not only because of the damage that it causes, but also because it has a wide host range. Infests many commercial crops such as leafy greens, cotton, green beans, and soybeans (Gallo et al., 2002).

Although the spider mite is considered as an occasional pest of soybeans, this arthropod species has increased in occurrence. The increase in reports of this soybean pest is probably related to the more common use of magnifying glasses to identify pests in the field, and at the same time, the presence of two-spotted spider mites on leaves has alerted the agricultural community to the problem (Haile and Higley, 2003).

According to Guedes et al., (2007), many factors may be contributed to the increases in spider mite populations in soybeans, mainly changes in the tillage system, such as weed control by the use of a genetically modified, glyphosate-tolerant variety, the commercial herbicide formulation which contains surfactants that may have an indirect effect on spider mites; the occurrence of soybean rust, which results in increased use of fungicides reducing the entomopathogenic fungi that regulate the spider-mite population and the intensive use of nonselective insecticides or acaricides.

Among the inappropriate insecticides are pyrethroids, which may contribute to spider-mite outbreaks, causing instability, increasing their incidence on plants and increasing the severity of symptoms caused by the mites (Degrande, 1998 \& Barros et al., 2007).

On the other hand, The increased population of spider mites in cotton is caused by the mortality of their natural enemies, dispersal, stimulation of spider-mite reproduction, physiological and nutritional changes in the plants, and the repellant effect on predators (Degrande 1998). However, another important factor affecting this increase in spider-mite populations in soybeans is the climate, (Haile and Higley, 2003). Moreover, dry weather favors reproduction and survival of this pest (Wright et al., 2006), because in such conditions the important biological control exerted by entomopathogenic fungi is almost nonexistent, (Klubertanz et al., 1991).

The spider mites feed by sucking the cell contents. The chloroplasts of the affected cells are disappear and the remaining material coagulates, forming a dead white mass in one end of the cells, causing a circular injury to the surrounding cells, which appears as a chlorotic spot (Gonçalves, 1996). The object of this study was to determine the damage threshold and economic injury level (EIL) of the red spider mite T. cucurbitacearum (Sayed), on soybean plants.

\section{Material and Methods}

Ecological studies conducted on the red spider mite, T. cucurbitacearum Magouz et al., (2006) evaluated the population density of the spider mite, T. cucurbitacearum (Sayed) on three soybean varieties (Giza21, Giza22 and Giza111).

An area of about $350 \mathrm{~m} 2$ cultivated with soybean cultive (Giza 111), variety in Hehyia distract, Sharkia Governorate was chosen for this study. Twenty plants of twenty days old age were selected on basis of size-homogenity and of being infested only by the red spider mite, T. cucurbitacearum (Sayed).

To estimate the population density of $T$. cucurbitacearum mite pest, weekly randomly 
samples of twenty leaflets from twenty plants were picked weekly, from all directions, including the central branches, of each plant by using marking plants technique. During the seasons of 2015 and 2016. The samples were transported to the laboratory for inspection, and the total number of alive individuals per leaflet were recorded. The means yield quantity were estimated before and after harvest per plant.

\section{Statistical analysis}

The effect of the population density of the mite, T. cucurbitacearum on the yield of soybean could be obtained through a preliminary analysis. According to Hosny et al., (1972) and Hassan (1998) using the partial regression formula "C-multiplier" (Fisher 1963). Three independents were considered in the regression process $\left(\mathrm{x}_{1}, \mathrm{x}_{2}\right.$ and $\left.\mathrm{x}_{3}\right)$. These represented the average number of alive adult mites per leaflet in
First peak $\left(\mathrm{x}_{1}\right)$, in second peak $\left(\mathrm{x}_{2}\right)$ and the average number of mite per plant during harvest time (x3). The yield per plant was taken as the dependent variate $(y)$.

\section{Results and discussion}

The yields of twenty soybean plants were arranged descendingly according to the amount of yields and corresponding the numbers of mites during three peaks in 2015 and 2016 seasons (Table $1)$.

The partial regression procedure helped in obtaining information about the amount of variability in the yield that could be accounted for by all the three infestation factors combined (the explained variance). Flechtmann (1985), in his study on this pest attacking tomatoes, observed that when the infestation is high, the mites diffuse over the entire plant.

Table1. The yield quantity of twenty soybean plants and the corresponding population density of $T$. cucurbitacearum, during 2015 and 2016 seasons.

\begin{tabular}{|c|c|c|c|c|c|c|c|c|}
\hline \multirow[b]{2}{*}{$\begin{array}{l}\text { Rep } \\
\text { No. }\end{array}$} & \multicolumn{4}{|c|}{2015 season } & \multicolumn{4}{|c|}{2016 season } \\
\hline & $\begin{array}{l}\text { Yield } \\
\text { in } \mathrm{g} \text {. } \\
(\mathrm{Y})\end{array}$ & $\begin{array}{l}\text { Total } \\
\text { number of } \\
\text { mites/leaflet } \\
\text { peak one } \\
\text { P1 }\left(\mathrm{x}_{1}\right)\end{array}$ & $\begin{array}{l}\text { Total } \\
\text { number of } \\
\text { mites/leaflet } \\
\text { peak two } \\
\mathrm{P} 2\left(\mathrm{x}_{2}\right)\end{array}$ & $\begin{array}{l}\text { Total } \\
\text { number of } \\
\text { mites/leaflet } \\
\text { peak three } \\
\text { P3 }\left(x_{3}\right)\end{array}$ & $\begin{array}{l}\text { Yield } \\
\text { in g. } \\
\text { (Y) }\end{array}$ & $\begin{array}{l}\text { Total } \\
\text { number of } \\
\text { mites/leaflet } \\
\text { peak one } \\
\mathrm{P} 1\left(\mathrm{x}_{1}\right)\end{array}$ & $\begin{array}{l}\text { Total } \\
\text { number of } \\
\text { mites/leaflet } \\
\text { Peak two } \\
\text { P2 }\left(\mathrm{x}_{2}\right)\end{array}$ & $\begin{array}{l}\text { Total } \\
\text { number of } \\
\text { mites/leaflet } \\
\text { peak three } \\
\text { P3 }\left(x_{3}\right)\end{array}$ \\
\hline 1 & 92.95 & 2 & 3 & 1 & 60.94 & 3 & 6 & 2 \\
\hline 2 & 40.45 & 5 & 7 & 2 & 56.49 & 4 & 6 & 8 \\
\hline 3 & 38.97 & 5 & 8 & 2 & 53.14 & 5 & 9 & 8 \\
\hline 4 & 38.46 & 8 & 8 & 3 & 50.4 & 5 & 10 & 8 \\
\hline 5 & 36.01 & 9 & 9 & 5 & 46.2 & 6 & 10 & 8 \\
\hline 6 & 35.04 & 10 & 10 & 9 & 35.25 & 6 & 11 & 9 \\
\hline 7 & 31.29 & 11 & 10 & 10 & 34.58 & 6 & 11 & 9 \\
\hline 8 & 29.94 & 12 & 11 & 10 & 33.11 & 7 & 12 & 11 \\
\hline 9 & 29.41 & 12 & 12 & 12 & 32.6 & 7 & 12 & 11 \\
\hline 10 & 29.04 & 13 & 13 & 15 & 31.3 & 8 & 12 & 12 \\
\hline 11 & 29.03 & 14 & 13 & 16 & 30.6 & 8 & 13 & 12 \\
\hline 12 & 29.01 & 16 & 16 & 16 & 28.81 & 10 & 16 & 12 \\
\hline 13 & 28.93 & 16 & 20 & 17 & 27.78 & 11 & 22 & 14 \\
\hline 14 & 28.18 & 19 & 21 & 17 & 27.5 & 11 & 23 & 14 \\
\hline 15 & 27.03 & 20 & 22 & 18 & 26.67 & 18 & 24 & 14 \\
\hline 16 & 27.01 & 21 & 22 & 21 & 25.92 & 19 & 31 & 16 \\
\hline 17 & 26.78 & 27 & 23 & 22 & 24.54 & 21 & 32 & 18 \\
\hline 18 & 14.38 & 33 & 25 & 23 & 22.09 & 22 & 33 & 19 \\
\hline & 14.29 & 42 & 26 & 23 & 22 & 23 & 40 & 20 \\
\hline 20 & 10.64 & 53 & 35 & 34 & 20.48 & 32 & 47 & 23 \\
\hline Total & 636.84 & 348 & 314 & 276 & 690.4 & 232 & 380 & 248 \\
\hline Mean & 31.842 & 17.4 & 15.7 & 13.8 & 34.52 & 11.6 & 19 & 12.4 \\
\hline
\end{tabular}


Obtained results in Table (2), indicated that the infestation factors $\left(\mathrm{x}_{1}, \mathrm{x}_{2}\right.$ and $\left.\mathrm{x}_{3}\right)$ were responsible, as a group for $53.68 \%$ and of the variability in the yield weights (y). The analysis of variance showed that the "F" value (6.18) was highly significant.

Similar results were obtained in 2016 season, where the responsibility of the infestation was $(80.28 \%)$, hence the significance of the "F" value was also highly significant Table 3.

To estimated the economic injury level for $T$. cucurbitacearum, firstly correcting the yield data for the effect of any two factors (as indicated by their partial regression values) thus having in the effect of third, and so on. The three equations used in this respect were as follows:

1. For the correction of the yield weight to $x_{2}$ and $x_{3}$ thus leaving only the effect of the first peak infestation $(\mathrm{x} 1): \mathrm{Yx}_{1}=\mathrm{Y} \pm\left[\mathrm{b} 2\left(\mathrm{x}_{2}-\mathrm{x}^{-} 2\right)+\mathrm{b} 3\left(\mathrm{x}_{3}-\mathrm{x}^{-} 3\right)\right]$

2. For the correction of the yield weight to $\mathrm{x} 1$ and $\mathrm{x} 3$ thus leaving only the effect of the second peak infestation $\left(\mathrm{x}_{2}\right): \mathrm{Yx}_{2}=\mathrm{Y} \pm\left[\mathrm{b} 1\left(\mathrm{x}_{1}-\mathrm{x}^{-} 1\right)+\mathrm{b} 3\left(\mathrm{x}_{3}-\mathrm{x}^{-} 3\right)\right]$

3. For the correction of the yield weight to $x 1$ and $x_{2}$ thus leaving only the effect of the third peak infestation $\left(\mathrm{x}_{3}\right): \mathrm{Yx}_{3}=\mathrm{Y} \pm\left[\mathrm{b} 1\left(\mathrm{x}_{1}-\mathrm{x}^{-} 1\right)+\mathrm{b} 2\left(\mathrm{x}_{2}-\mathrm{x}^{-} 2\right)\right]$

Table 2. Statistical analysis (simple correlations, partial regressions and explained variance) of the relationship end effect of 3 infestation factors on the yield of 2015

\begin{tabular}{lcccccc}
\hline Tested counts & \multicolumn{2}{c}{ Simple correlation } & \multicolumn{2}{c}{ Regression values } & Explained \\
\cline { 2 - 6 } variance $\%$
\end{tabular}

So, having obtained three new corrected values for the yield of each plant, assumed to reflect the effect of only one infestation factors, it was possible to calculate a simple regression for each one. The method of "Least squares" was applied. In this way the gradual effect of infestation unit on the yield could be worked out for each factors. The main idea in this connection was to determine the slope of the regression line in each case.

But at the yield quantity and the level of infestation relationship is more or less curved rather than linear, thus a curved regression line had to be fitted. This could be accomplished by transforming the "y" values (dependent variables) in the common regression equation $(y=a+b x)$ into their logarithms using the following equation: $y=e^{-}(a+b x)$ (i.e. Log $. \mathrm{y}=\mathrm{a}+\mathrm{b} \mathrm{x}$ ).

The constants "a" and "b" in that equation were determined as follows:

$\mathrm{a}=1 / \mathrm{n} \log \cdot \mathrm{y}-\mathrm{b} \Sigma \mathrm{x}$

$\mathrm{b}=\frac{\mathrm{n}\left(\sum \mathrm{x} \cdot \log \cdot \mathrm{y}\right)-\sum \mathrm{x} \cdot \sum \log \cdot \mathrm{y}}{\mathrm{n} \sum \mathrm{x}^{2}-\left(\sum \mathrm{x}\right)^{2}}$

Mathematically, the calculated values of (y) form a curve when they are retransformed to ordinary numbers (antilogs).

Table 3. Statistical analysis (simple correlations, partial regressions and explained variance) of the relationship end effect of 3 infestation factors on the yield of 2016

\begin{tabular}{|c|c|c|c|c|c|c|c|}
\hline \multirow{2}{*}{ Tested counts } & \multicolumn{2}{|c|}{ Simple correlation } & \multicolumn{4}{|c|}{ Regression values } & \multirow[t]{2}{*}{$\begin{array}{l}\text { Explained } \\
\text { variance \% }\end{array}$} \\
\hline & $\mathrm{r}$ & $\mathrm{p}$ & $\mathrm{b}$ & se & $\mathrm{t}$ & $\mathrm{p}$ & \\
\hline $\begin{array}{l}\text { Number of mite /leaflet in } \\
1^{\text {st }} \operatorname{peak}\left(x_{1}\right)\end{array}$ & 0.9737224 & 0 & 0.7137882 & 0.9183895 & 0.7772172 & 0.4484 & 80.28 \\
\hline $\begin{array}{l}\text { Number of mite /leaflet in } \\
2^{\text {nd }} \text { peak }\left(x_{2}\right)\end{array}$ & 0.9766196 & 0 & 0.1421685 & 0.6697873 & 0.2122592 & 0.8346 & \\
\hline $\begin{array}{l}\text { Number of mite /leaflet in } \\
3^{\text {rd }} \operatorname{peak}\left(x_{3}\right)\end{array}$ & 0.985286 & 0 & -3.512632 & 0.8622887 & -4.073615 & 0.0009 & \\
\hline
\end{tabular}

The population density of mite, $T$. cucurbitacearum infested soybean plant showed three peaks of activity during 2015 and 2016 seasons. The obtained results indicated that the rate of reduction in the yield of soybean differs from one infestation level to another one in the two seasons of 2015 and 2016. Tables (4\&5), also it is worth to mention that the $1^{\text {st }}$ peak infestation had a consistently strong yield lowering effect. Such consistency was not quite obvious with the second and third peak of infestation (Fig 1).

These results are agree with the findings of Fadini et al., (2004) and Magouz et al., (2006), who mounted that the injury caused by the two-spotted spider mite results from perforation of the lower epidermis cells, and high infestations of mites reduce the rate of photosynthesis, which it may due to damaging the leaf mesophyll and causing the stomata to close. 

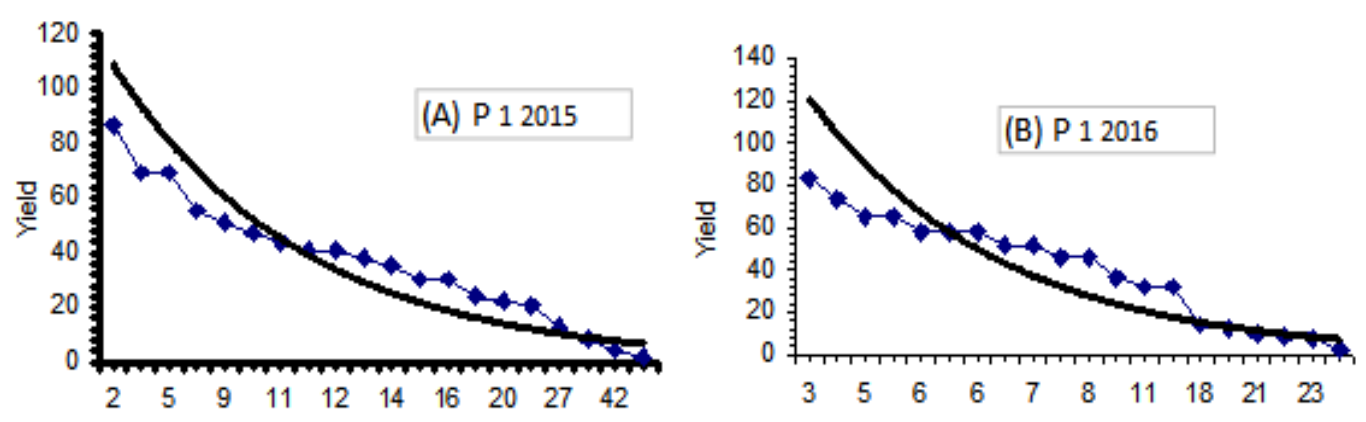

Number of living mites per leaflet
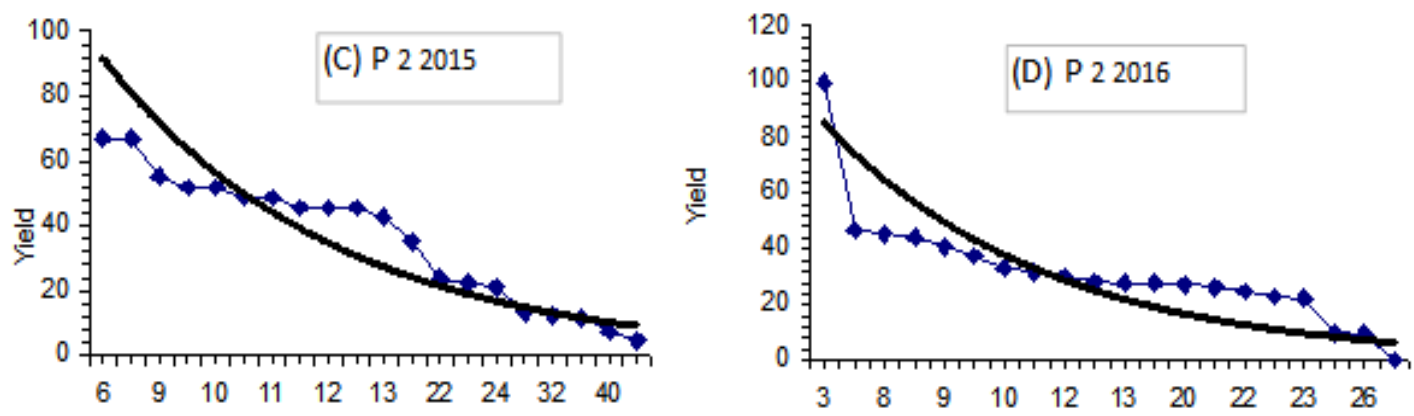

Number of living mites per leaflet
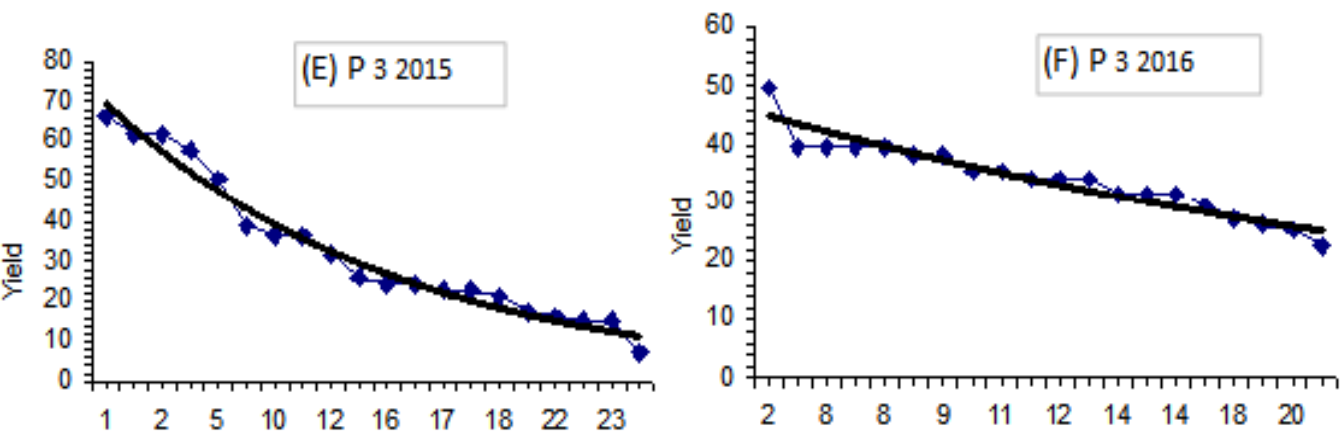

Number of living mites per leaflet

Fig. 1: corrected number of soybean yields (y) /quantity during the three peaks of T. cucurbitacearum during 2015 and 2016 seasons 
Table 4. Gradual decrease in the corrected values of soybean yield caused by the increase in the infestation rate of T. cucurbitacearum over three peaks of seasonal population density during 2015 season

\begin{tabular}{|c|c|c|c|c|c|c|c|c|}
\hline $\begin{array}{l}\text { Total } \\
\text { no. of } \\
\text { mites }\left(1^{\text {st }}\right. \\
\text { peak) } \\
\text { /leaflet }\end{array}$ & $\begin{array}{l}\text { Corrected } \\
\text { values of } \\
\text { yield (g./ } \\
\text { plant)Y }\end{array}$ & $\begin{array}{l}\text { Calculated } \\
\text { values of } \\
\text { yield (g./ } \\
\text { plant)Y }\end{array}$ & $\begin{array}{c}\text { Total } \\
\text { no. of } \\
\text { mites ( in } \\
2^{\text {nd }} \text { peak) } \\
\text { /leaflet }\end{array}$ & $\begin{array}{l}\text { Corrected } \\
\text { values of } \\
\text { yield (g./ } \\
\text { plant)Y }\end{array}$ & $\begin{array}{l}\text { Calculated } \\
\text { values of } \\
\text { yield in } g \\
\text { (Y) }\end{array}$ & $\begin{array}{c}\text { Total } \\
\text { no. of } \\
\text { mites (in } \\
3^{\text {rd }} \text { peak) } \\
\text { /leaflet }\end{array}$ & $\begin{array}{c}\text { Corrected } \\
\text { values of } \\
\text { yield (g./ } \\
\text { plant)Y }\end{array}$ & $\begin{array}{l}\text { Calculated } \\
\text { values of } \\
\text { yield (g./ } \\
\text { plant)Y }\end{array}$ \\
\hline 2 & 112.14 & 86.9301 & 6 & 99.75 & 64.1984 & 1 & 104.19 & 66.0986 \\
\hline 5 & 55.35 & 69.3495 & 6 & 46.79 & 64.1984 & 2 & 48.08 & 61.8473 \\
\hline 5 & 52.94 & 69.3495 & 9 & 45.31 & 50.9506 & 2 & 45.67 & 61.8473 \\
\hline 8 & 51.85 & 55.3245 & 10 & 44.33 & 47.1727 & 3 & 45.27 & 57.8694 \\
\hline 9 & 47.32 & 51.3108 & 10 & 40.77 & 47.1727 & 5 & 41.93 & 50.6647 \\
\hline 10 & 43.11 & 47.5882 & 11 & 37.53 & 43.6750 & 9 & 40.07 & 38.8346 \\
\hline 11 & 40.24 & 44.1358 & 11 & 33.24 & 43.6750 & 10 & 36.35 & 36.3369 \\
\hline 12 & 38.78 & 40.9338 & 12 & 31.93 & 40.4366 & 10 & 34.11 & 36.3369 \\
\hline 12 & 36.50 & 40.9338 & 12 & 30.25 & 40.4366 & 12 & 32.65 & 31.8130 \\
\hline 13 & 33.89 & 37.9641 & 12 & 28.18 & 40.4366 & 15 & 31.42 & 26.0609 \\
\hline 14 & 30.86 & 35.2099 & 13 & 27.69 & 37.4383 & 16 & 31.39 & 24.3847 \\
\hline 16 & 30.27 & 30.2863 & 16 & 27.63 & 29.7126 & 16 & 28.68 & 24.3847 \\
\hline 16 & 29.18 & 30.2863 & 22 & 27.03 & 18.7151 & 17 & 27.27 & 22.8164 \\
\hline 19 & 27.46 & 24.1613 & 23 & 26.40 & 17.3274 & 17 & 24.88 & 22.8164 \\
\hline 20 & 23.08 & 22.4084 & 24 & 24.71 & 16.0426 & 18 & 23.31 & 21.3489 \\
\hline 21 & 21.40 & 20.7827 & 31 & 22.99 & 9.3555 & 21 & 21.28 & 17.4888 \\
\hline 27 & 18.75 & 13.2267 & 32 & 22.41 & 8.6618 & 22 & 21.27 & 16.3640 \\
\hline 33 & 17.00 & 8.4178 & 33 & 9.91 & 8.0196 & 23 & 20.35 & 15.3115 \\
\hline 42 & 15.26 & 4.2738 & 40 & 9.66 & 4.6767 & 23 & 6.31 & 15.3115 \\
\hline 53 & 0.42 & 1.8665 & 47 & 0.33 & 2.7273 & 34 & 5.63 & 7.3693 \\
\hline $\mathrm{b}$ & -0.0327 & & $\mathrm{~b}$ & -0.0335 & & $\mathrm{~b}$ & -0.0289 & \\
\hline $\mathrm{a}$ & 2.0046 & & $\mathrm{a}$ & 2.0083 & & $\mathrm{a}$ & 1.8491 & \\
\hline
\end{tabular}

Table 5. Gradual decrease in the corrected values of soybean yield causing by the increase in the infestation rate of T. cucurbitacearum over three peaks of seasonal population density during 2016 season

\begin{tabular}{|c|c|c|c|c|c|c|c|c|}
\hline $\begin{array}{c}\text { Total } \\
\text { no. of } \\
\text { mites } \\
\left(1^{\text {st }}\right. \\
\text { peak }) \\
/ \text { leaflet }\end{array}$ & $\begin{array}{l}\text { Corrected } \\
\text { values of } \\
\text { yield (g./ } \\
\text { plant)Y }\end{array}$ & $\begin{array}{l}\text { Calculated } \\
\text { values of } \\
\text { yield (g./ } \\
\text { plant)Y }\end{array}$ & $\begin{array}{c}\text { Total no. } \\
\text { of mites } \\
\left(2^{\text {nd }}\right. \\
\text { peak }) \\
\text { /leaflet }\end{array}$ & $\begin{array}{l}\text { Corrected } \\
\text { values of } \\
\text { yield (g./ } \\
\text { plant)Y }\end{array}$ & $\begin{array}{l}\text { Calculated } \\
\text { values of } \\
\text { yield (g./ } \\
\text { plant)Y }\end{array}$ & $\begin{array}{c}\text { Total } \\
\text { no. of } \\
\text { mites } \\
\left(3^{\text {rd }}\right. \\
\text { peak }) \\
\text { /leaflet }\end{array}$ & $\begin{array}{l}\text { Corrected } \\
\text { values of } \\
\text { yield (g./ } \\
\text { plant)Y }\end{array}$ & $\begin{array}{l}\text { Calculated } \\
\text { values of } \\
\text { yield (g./ } \\
\text { plant)Y }\end{array}$ \\
\hline 3 & 95.62 & 83.0807 & 6 & 91.33 & 67.1412 & 2 & 52.95 & 49.7620 \\
\hline 4 & 70.10 & 73.8112 & 6 & 66.52 & 67.1412 & 8 & 49.22 & 39.7517 \\
\hline 5 & 67.17 & 65.5758 & 9 & 63.88 & 55.3479 & 8 & 47.01 & 39.7517 \\
\hline 5 & 64.58 & 65.5758 & 10 & 61.14 & 51.8965 & 8 & 44.41 & 39.7517 \\
\hline 6 & 60.38 & 58.2594 & 10 & 57.66 & 51.8965 & 8 & 40.92 & 39.7517 \\
\hline 6 & 53.73 & 58.2594 & 11 & 43.20 & 48.6603 & 9 & 39.02 & 38.2911 \\
\hline 6 & 46.06 & 58.2594 & 11 & 43.15 & 48.6603 & 9 & 33.12 & 38.2911 \\
\hline 7 & 45.71 & 51.7592 & 12 & 42.53 & 45.6260 & 11 & 33.10 & 35.5291 \\
\hline 7 & 45.39 & 51.7592 & 12 & 34.74 & 45.6260 & 11 & 32.91 & 35.5291 \\
\hline 8 & 37.03 & 45.9843 & 12 & 34.23 & 45.6260 & 12 & 31.95 & 34.2237 \\
\hline 8 & 36.52 & 45.9843 & 13 & 30.14 & 42.7809 & 12 & 31.50 & 34.2237 \\
\hline 10 & 31.71 & 36.2955 & 16 & 29.44 & 35.2664 & 12 & 30.12 & 34.2237 \\
\hline 11 & 31.15 & 32.2459 & 22 & 29.07 & 23.9654 & 14 & 29.45 & 31.7550 \\
\hline 11 & 29.79 & 32.2459 & 23 & 25.62 & 22.4709 & 14 & 28.83 & 31.7550 \\
\hline 18 & 22.59 & 14.0873 & 24 & 21.73 & 21.0697 & 14 & 28.32 & 31.7550 \\
\hline 19 & 22.45 & 12.5155 & 31 & 21.45 & 13.4251 & 16 & 27.78 & 29.4645 \\
\hline 21 & 21.76 & 9.8785 & 32 & 18.56 & 12.5880 & 18 & 27.74 & 27.3391 \\
\hline 22 & 14.98 & 8.7764 & 33 & 11.58 & 11.8030 & 19 & 27.64 & 26.3346 \\
\hline 23 & 6.72 & 7.7972 & 40 & 6.33 & 7.5206 & 20 & 27.24 & 25.3671 \\
\hline 32 & 0.90 & 2.6886 & 47 & 3.44 & 4.7920 & 23 & 27.18 & 22.6725 \\
\hline $\mathrm{b}$ & -0.0514 & & $\mathrm{~b}$ & -0.0280 & & $\mathrm{~b}$ & -0.0163 & \\
\hline $\mathrm{a}$ & 2.0736 & & $\mathrm{a}$ & 1.9948 & & $\mathrm{a}$ & 1.7294 & \\
\hline
\end{tabular}


The economic damage- level is simply the point at which the yield quantity at the upper part of the curved regression slope starts to show a significant twist. Above such a point all weight-figures are assumed to be statistically similar. The infestation level corresponding to that particular point may safely be regarded as the economic damage threshold. Practically speaking once the infestation reaches that point immediate measure of chemical control becoming inevitable in order to stop the insignificant yield-reduction from becoming significant.

To locate precisely that point on the smoothed curve the method of Chi-square analysis termed $\mathrm{r} \times 2$ contingency tables with no expectation (Bailey 1959) was applied to the $y$ data. The following example demonstrates the details of this procedure (as used to find out the damage-threshold for the first peak infestation, Table 6).

Table 6 .The change in the soybean yield quantity by increasing the population density of T. cucurbitacearum during the First peak in 2015 season

\begin{tabular}{cccc}
\hline $\begin{array}{c}\mathrm{X}_{1} \\
\text { Mites / leaflet }\end{array}$ & $\mathrm{Y}$ & Log.y & $\mathrm{Y}=\mathrm{e}-(\mathrm{a}+\mathrm{bx})$ \\
\hline 2 & 112.14 & 2.0498 & 86.9301 \\
5 & 55.35 & 1.7431 & 69.3495 \\
5 & 52.94 & 1.7237 & 69.3495 \\
8 & 51.85 & 1.7147 & 55.3245 \\
9 & 47.32 & 1.6750 & 51.3108 \\
10 & 43.11 & 1.6346 & 47.5882 \\
11 & 40.24 & 1.6047 & 44.1358 \\
12 & 38.78 & 1.5887 & 40.9338 \\
12 & 36.50 & 1.5623 & 40.9338 \\
13 & 33.89 & 1.5301 & 37.9641 \\
14 & 30.86 & 1.4894 & 35.2099 \\
16 & 30.27 & 1.4811 & 30.2863 \\
16 & 29.18 & 1.4650 & 30.2863 \\
19 & 27.46 & 1.4387 & 24.1613 \\
20 & 23.08 & 1.3633 & 22.4084 \\
21 & 21.40 & 1.3305 & 20.7827 \\
27 & 18.75 & 1.2729 & 13.2267 \\
33 & 17.00 & 1.2304 & 8.4178 \\
42 & 15.26 & 1.1836 & 4.2738 \\
53 & 0.42 & -0.3726 & 1.8665 \\
$\mathrm{~b}$ & -0.0327 & 1.7431 & 69.3495 \\
\hline
\end{tabular}

Similar calculations were made to determine the threshold for second and third peaks of infestation levels. The reduction in the yield varied it may be due to different manner of infestation in each peak.

The infestation at the first peak $\left(\mathrm{X}_{1}\right)$ showed more high effect on the yield where, $(b=-0.0327)$ while in other two peaks $\left(\mathrm{X}_{2}, \mathrm{X}_{3}\right)$ (regression value average $" b "=-0.335$ and -0.00289$)$ respectively during 2015. In the second season of 2016 the infestation effects could be arranged descendingly to $X_{1}, X_{2}$ and $\mathrm{X}_{3}(-0.0514,-0.0280$ and -0.0163$)$, respectively.

Mathematic determination of the point at which the increase of mite number through the three peaks of infestation $\left(\mathrm{X}_{1}, \mathrm{X}_{2}\right.$ and $\left.\mathrm{X}_{3}\right)$ for the two seasons caused a drop in the weight of yield, the "Chi-square" analysis $\left(\mathrm{r} \mathrm{X}_{2}\right)$ was applied.

Results indicated that the economic injury level was affected by the three peaks infestation peaks. In the first season of 2015 the population density during the first peak of infestation increased from 27 to 33 individuals/ 20 leaflet, resulting insignificant reduction in yield from 13.23 to $8.42 \mathrm{~g}$ / plant. For the second peak the increase of infestation from 16 to 22 individuals./ 20 leaflet decreased soybean yield insignificantly from 29.71 to $18.71 \mathrm{~g} /$ plant. For the third peak the increase of infestation from 3 to 9 individuals $/ 20$ leaflet decreased soybean yield insignificantly from 57.87 to $38.83 \mathrm{~g} /$ plant.

The economic threshold level for three peaks in the first season was 30.29 individuals/ 20 leaflet in the first peak, while it was 27.03 and 38.83 individuals/ 20 leaflet for both second and third peaks of activity in the first season respectively. Economic injury level for three peaks during the first season (2015) which were 24.16, 26.40 and36.34 individuals/ 20 leaflet.

In the season of 2016 for three peaks, the increase of infestation from 23 to 32 individuals/ 20 leaflet decreased soybean yield insignificantly from 7.79 to $2.69 \mathrm{~g} /$ plant, in the first peak, in both second and third peaks the increase of infestation was $16-22 \& 2-$ 8 individuals/ 20 leaflet, decreased soybean yield insignificantly 35.27 to 23.97 for the second peak and 49.76to $39.75 \mathrm{~g} /$ plant for the third peak.

The economic threshold level for three peaks was $32.25,23.97$ and 31.76 individuals/ 20 leaflet. The 
economic injury level for three peaks also were, 14.09, 22.47 and 29.46 individuals/ 20 leaflet. Data in (Table 7) revealed that the mean values of economic threshold and economic injury levels in both seasons for three peaks $\left(\mathrm{X}_{1}, \mathrm{X}_{2} \& \mathrm{X}_{3}\right)$ were $15.64,12.75$ and 35.30 individuals / leaflet for economic threshold level and 9.5, 12.22 and 32.9 individuals / leaflet for economic injury level.

Table 7. Mean values of economic threshold and economic injury levels for T.cucurbitacearum by using plants technique during 2015 and 2016 seasons

\begin{tabular}{|c|c|c|c|c|c|c|c|c|c|c|}
\hline \multirow{2}{*}{ Seasons } & \multicolumn{2}{|c|}{$\begin{array}{l}\text { Total number of } \\
\text { mites /leaflet }\left(\mathrm{X}_{1}\right)\end{array}$} & \multicolumn{2}{|c|}{$\begin{array}{l}\text { Total number of } \\
\text { mites /leaflet }\left(X_{2}\right)\end{array}$} & \multicolumn{2}{|c|}{$\begin{array}{l}\text { Total number of } \\
\text { mites /leaflet }\left(\mathrm{X}_{3}\right)\end{array}$} & \multicolumn{2}{|c|}{$\begin{array}{c}\text { Total }\left(\mathrm{X}_{1}, \mathrm{X}_{2} \&\right. \\
\left.\mathrm{X}_{3}\right) \\
\end{array}$} & \multicolumn{2}{|c|}{ Mean } \\
\hline & E.T.L & E.I.L & E.T.L & E.I.L & E.T.L & E.I.L & E.T.L & E.I.L & E.T.L & E.I.L \\
\hline 2015 & 30.29 & 24.16 & 27.03 & 26.40 & 38.83 & 36.34 & 96.15 & 86.9 & 32.05 & 28.97 \\
\hline 2016 & 32.25 & 14.09 & 23.97 & 22.47 & 31.76 & 29.46 & 87.98 & 66.02 & 29.33 & 22.01 \\
\hline Total & 31.27 & 19.13 & 25.5 & 24.44 & 70.59 & 65.8 & 127.36 & 109.37 & 42.45 & 36.46 \\
\hline Mean & 15.64 & 9.5 & 12.75 & 12.22 & 35.30 & 32.9 & 63.69 & 54.62 & 21.23 & 18.21 \\
\hline
\end{tabular}

Generally, the mean value of economic injury level during the first season 2015 was 28.97 , while mean value of economic threshold level was 32.05 individuals / leaflet. In second season 2016 the mean value of economic injury level was 22.01 individuals /leaflet and the mean value of economic threshold level was 29.33 individuals /leaflet. ETL lies around an average infestation level of 21.23 individual per leaflet, while the EIL around an average infestation level of 18.21 individual per leaflet.

\section{Acknowledgment}

Thanks for our Prof. Dr. Mohamed Nada and Prof. Dr. A. Sh. Hassan for their helps in this work.

\section{References}

Baily, N. T. J.; (1969): Statistical methods in biology. The English University Press LTD., London.

Barros, R., Degrande, P.E., Soria, M.F., \& Ribeiro, J.S.F.; (2007): Biological imbalance of the spider mite Tetranychus urticae Koch, 1836 (Acari: Tetranychidae) after cotton on insecticide applications. Arq. Inst. Biol. 74 (2): 171-174p.

Degrande, P.E.; (1998): Integrated management of cotton pests. In Embrapa. Center for Agricultural Research of the West (Dourados, MS). Cotton: Technical information. 154-191p.

Fadini, M.A.M., Lemos, W.P., Pallini, A., Venzon, M., \& Mourão, S.A.; (2004): Herbivory of Tetranychus urticae Koch (Acari: Tetranychidae) induces direct defense in strawberry. Neotropical entomology, 33(3): 293-297p.

Fisher, R. A., (1963): Statistical methods for research workers. Oliver and Boyed, Edinburgh and London.

Flechtmann, C. H.W., (1985): Ácaros de importância agrícola. 6a . Ed. São Paulo, Nobel, $169 \mathrm{p}$.

Gallo, D.; Nakano, O.; Neto, S. S.; Carvalho, R. P.L.; Baptista, G. C.; Filho, E. B.; Parra, J.R.P.; Zucchi, R. A.; Alves, S.B.; Vendramin, J.D.; Lopes, J.R.S.; and Omoto, C. (2002):
Entomologia Agrícola. Piracicaba, Editora Agronômica Ceres, 920p.

Guedes, J.V.C.; Navia, D.; Lofego, A.C.; and Dequech, S.T.B. (2007): Ácaros associados à cultura da soja no Rio Grande do Sul, Brasil. Neotropical Entomology, 36:288-293.

Gonçalves, M. I. F.; (1996): Variação do teor de 2tridecanona em folíolos de tomateiro e sua relação com a resistência a duas espécies de ácaros do gênero Tetranychus. Dissertação de Mestrado, Universidade Federal de Lavras, Lavras. 63p.

Haile, F.J. and Higley, L.G.; (2003) Changes in soybean gas-exchange after moisture stress and spider mite injury. Environmental Entomology, 32:433-440.

Hassan, A. Sh., (1998): Studies on some scale insects and mealybugs infesting certain horticulture crops in newly reclaimed areas. Ph.D. Thesis. Fac. Agric., Zagazeig Univ.,167 pp.

Hosny, M.M.; Amin, A. H. and El-Saadany, G. B. (1972): The damage threshold of the red scale, Aonidiella aurantii (Maskell) infesting mandarin trees in Egypt. Z. ang. Ent., 71:286-296.

Klubertanz, T.H.; Pedigo, L.P. and Carlson, R.E.; (1991): Impact of fungal epizootics on the biology and management of the two-spotted spider mite (Acari: Tetranychidae) in soybean. Environmental Entomology, 20:731-735.

Magouz, R. I. E.; Sohair, E. Saadoon and Kassem, S. A. A. (2006): Population density of Tetranychus cucurbitacearum (Sayed) and Bemisia tabaci (Genn.) on certain soybean varieties in relation to some weather factors and leaf chemical contents. J. Agric. Res. Tanta Univ., 3 (1): 90-102.

Wright, R.; Seymour, R.; Higley, L. and Campbell, J. (2006): Spider mite management in corn and soybeans. NebGuide, G1167. University of Nebrasca, Lincoln, Institute of Agriculture and Natural Resources disponível em: www.ianrpubs.unl.edu/epublic/live/ g1167/build/g1167.pdf. Acessado em 15 de fevereiro de 2012. 


\section{الحدود الإقتصادية الحرجة وحدود الضرر للحم العنكبوتي Tetranychus cucurbitacearum علي محصول}

فول الصويا

$$
\text { معهد بحوث وقاية النباتات - مركزة البحوث الزراعية - الجيزة - مصر. }
$$

Tetranychus أجريـت دراسـات الحـــ الإقتصـادي الحـرج ومسـتوي الضـرر الإقتصـادي علـي الحــم العنكبـوتي ذو البقعتـين علي محصول فول الصويا في مساحة .0 cucurbitacearum باتباع طريقه النباتات المعلمة.

وأوضحت النتائج أن هناك إختلافات في قيم الحدود الاقتصادية الحرجه والحدود الإقتصادية للضرر . فقد كان منوسط الحد الإقتصادي

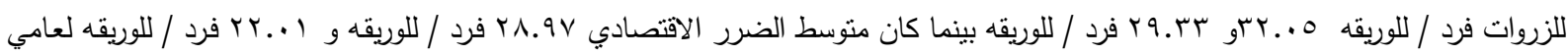

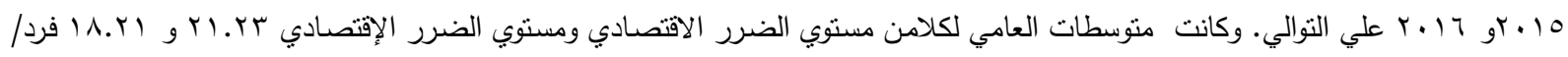
للوريقه. 